\author{
Seni dan Budaya Tobelo \\ Dolfina Galela \\ dolfinagalela@gmail.com \\ Djeinnie Imbang \\ Christian G. Ranuntu \\ Pascasarjana \\ Universitas Sam Ratulangi
}

\begin{abstract}
Arts and Culture is everything created humans evolved about how to live together in a group that contains elements of beauty (aesthetics) are down from generation to generation. Not unlike the other regions which have respective areas of art and culture - each. Likewise with Tobelo, which has a strong arts culture, which has a value - the value of cultural hereditary as well as in public life cherish in Tobelo. This study takes the subject of efforts to maintain the existence of cultural arts Tobelo.

The purpose of this study is to identify and classify the arts and culture district Tobelo northern Halmahera, North Maluku Province. The results showed that the Cultural Arts Tobelo 'strong as the heritage of art and culture that is passed down from one generation to the next have got education of art and culture since childhood.

Keywords: Arts and Culture, Tobelo
\end{abstract}

\title{
Pendahuluan
}

Bahasa Indonsia sudah menjadi alat komunikasi dalam kehidupan sehari - hari. Bahasa sebagai alat komunikasi lisan ataupun tulisan merupakan salah satu unsur penting yang mencerminkan kebudayaan masyarakat pemakainya. Bahasa tidak hanya digunakan sebagai alat komunikasi sosial tetapi juga dapat berfungsi sebagai alat pengungkap pikiran dan perasaan yang mencerminkan pandangan hidup atau pola pikir masyarakat. Dengan kata lain, bahasa dapat mengungkapkan pikiran, perasaan, dan nilai - nilai bahasa ketika bahasa itu dipakai dalam berinteraksi dengan sesama dan lingkungannya sekitarnya.

Hal di atas lebih dipertegas lagi melalui Hipotesis Sapir-Whorf yang mengemukakan bahwa bahasa bukan hanya menentukan cara berpikir manusia tapi juga mempengaruhi tingkah lakunya (Havilland, 1985:394).

Seni pada mulanya adalah proses dari manusia, dan oleh karena itu merupakan sinonim dari ilmu. Dewasa ini, seni bisa dilihat dalam intisari ekspresi dari kreatifitas 
manusia. Seni sangat sulit untuk dijelaskan dan juga sulit dinilai, bahwa masing - masing induvidu artis memilih sendiri peraturan dan parameter yang menuntunnya atau kerjanya, masih bisa dikatakan bahwa seni adalah proses dan produk dari memilih medium, dan suatu set peraturan untuk penggunaan medium itu, dan suatu set nilai - nilai yang menentukan apa yang pantas dikirimkan dengan ekspresi lewat medium itu, untuk menyampaikan baik kepercayaan, gagasan, sensasi, atau perasaan dengan cara seefektif mungkin untuk medium itu. Adapun beberapa teori seni menurut beberapa tokoh: Ki. Hadjar Dewantara seni adalah segala perbuatan manusia yang timbul dan bersifat indah, menyenangkan dan dapat dapat menggerakan jiwa manusia. Kemudian dari Ahdiat Karta Miharja seni adalah kegiatan rohani yang merefleksi pada jasmani, dan mempunyai daya yang bisa membangkitkan perasaan/jiwa orang lain.

Pernyataan Sapir yang dikutip Silzer (1990) bahwa kandungan setiap budaya dapat terungkap di dalam bahasanya. Demikian pula, pernyataan Nababan (1984) via Silzer (1990) bahwa untuk mengerti suatu kebudayaan secara mendalam kuncinya adalah bahasa. Dalam bahasa adat Galela khususnya yang berkaitan dengan bahasa adat upacara peminangan terkandung kebudayaan masyarakatnya, juga terdapat suatu kerja sama yang baik antarsesama anggota masyarakat etnik Galela dan pemakaian bahasa yang digunakan secara aktif dalam berkomunikasi pada upacara adat walaupun mereka berada di luar daerah asal sehingga merupakan objek studi linguistik yang sangat menarik untuk dikaji. Dengan demikian, penelitian terhadap bahasa adat Galela dalam upacara peminangan merupakan suatu upaya pemahaman terhadap bagian dari kebudayaan masyarakat etnik melalui "jendela" bahasa.

Budaya adalah pikiran, akal budi, yang didalamnya termasuk adat istiadat, (Sugono, 2005:169). Dengan demikian, budaya dapat diartikan sebagai sesuatu yang dihasilkan dari pikiran atau pemikiran. Maka takkala ada ahli menyebutkan bahwa bahasa dan pemikiran memiliki hubungan timbal-balik dapat dipahami bahwa pikiran di sini dimaksudkan sebagai sebuah perwujudan kebudayaan. Budaya adalah seluruh sistem gagasan dan rasa, tindakan, serta karya yang dihasilkan manusia dalam kehidupan bermasyarakat (Keontjaraningrat, 2011:72).

Tobelo menghitung hubungan keturunan berdasarkan garis ayah (patrilineal), dengan pola menetap setelah kawin yang patrilokal, tapi pada masa sekarang cenderung untuk lebih neolokal. Namun dalam kehidupan sehari-hari mereka selalu menjaga 
hubungan bilateral dalam kekerabatannya, sehingga ahli asing ada yang beranggapan bahwa sistem kekerabatan orang Tobelo adalah bilateral. Seni budaya masyarakat Halmahera Utara merupakan pancaran ketulusan jiwa dan semangat mensyukuri akan karunia Tuhan Yang Maha Kuasa terhadap tanah persadanya. Ini terungkap dari berbagai jenis kesenian yang selalu mewarnai setiap upacara seremonial adat maupun upacaraupacara sakral yang dipentaskan pada setiap kesempatan. Pemahaman ini disebut $O$ Guru'mini Ma'oa Awi'ngale yang artinya Yang Kuasa Mengilhami.

Budaya merupakan hal yang tidak pernah lepas dari daerah propinsi maluku utara, daerah disini merupakan daerah yang benar-benar menghargai budaya dan tidak pernah lepas dengan budaya. salah satunya daerah tobelo kabupaten halmahera utara, salah satu kota kabupaten di maluku utara. Awal mula disini budaya hanya dipandang sebelah mata, hanya 1 orang yang benar benar masih menghargai budaya, masih mempunyai idealis untuk menjunjung tinggi budaya tobelo, dia adalah Yesaya banari. dia kini jadi budayawan terkenal di tobelo.

Pada tahun 2000 tobelo telah membuat gerakan kebudayaan sebagai modal sosial untuk mempersatukan kembali tali persaudaraan mereka yang sebelumnya telah ada namun belum terpublikasikan, hal ini terbukti dengan adanya rumah adat hibualamo, rumah adat ini berada di tengah kota tobelo rumah adat ini digunakan suku tobelo sebagai tempat berkumpul bersama, saling berbagi cerita dan sebagainya. selain itu juga bapak yesaya banari telah membuat gerakan kebudayaan dengan membuat kediamannya yang berada di tanjung pilawang rumah dengan konstruksi bangunannya persis rumah asli suku tobelo terdahulu dan diberi nama dabiloha yang artinya indah/bagus. selain itu bapak yesaya juga membina anak-anak di rumah dabiloha sebanyak 80 orang, anak-anak tersebut bukan hanya suku tobelo namun ada beberapa suku campuran lainnya misalnya jawa, bugis yang senang dengan suku tobelo dan mencintai adat tobelo.

Pak Yesaya mengumpulkan orang-orang pencinta budaya tersebut dalam sanggar yang dibuatnya, "gomi goraci" namanya, yang berarti tali emas, sanggar ini dijadikan sebagai tempat latihan, tempat mencari ilmu mengenai kebudayaaan. Banyak prestasi yang sudah didapat, baik tingkat nasional ataupun daerah, di daerah, budaya tobelo menjadi juara umum pada prestasi tingkat provinsi, untuk tari daerah, musik daerah, seni dan budaya. Pada tingkat nasional pertama tahun 1999 menjadi juara pada kejuaraan nasional, 
pada tahun 2009 tampil di pasar seni di belanda, dan pada tahunn 2009 budaya tobelo ini melakukan pemecaham MURI 3000 penari dan musik yangere dan tarian cakalele.

Budaya yang terus dilestarikan oleh sanggar ini dengan masyarakat pencinta budaya lainnya adalah seperti pesta gomatere yaitu pesta setelah panen, O hoya tarian cakalele, kabata talaga lina yaitu upacara adat pengambilan ikan yang naik di laut, dan tokuwela yaitu tari semangat kebersamaan dengan penari saling berpegangan tangan dan orang naik diatasnya, ini menggambarkan kebersamaan orang-orang tobelo.

Penelitian ini merupakan penelitian yang mengkaitkan seni dan budaya tobelo. Sejauh pengamatan yang dilakukan melalui penelusuran pustaka, belum pernah dilakukan penelitian serupa oleh para peneliti terdahulu. Karena itu, penelitian ini tidak diragukan keasliaannya.

\section{Perumusan Masalah}

Berdasarkan latar belakang pemikiran diatas, maka yang akan menjadi masalah dalam penelitian ini, yaitu Seni dan Budaya apa saja yang ada di Tobelo ?

\section{Tujuan Menelitian}

Berdasarkan permasalahan yang dilakukan, maka tujuan penelitian ini yaitu mengidentifikasi dan mengklasifikasi seni dan budaya tobelo.

\section{Manfaat Penelitian}

Mengaju pada tujuan yang ingin dicapai, maka penelitian ini diharapkan dapat bermanfaat baik secara teoritis maupun praktis.

\section{Manfaat Teoritis}

Hasil Penelitian ini untuk memberi kontribusi untuk teori linguistik, terutama linguistik antropologi yang berkaitan dengan budaya Tobelo.

\section{Manfaat Praktis}

Hasil penelitian ini bermanfaat bagi masyarakat Maluku Utara, dalam rangka pelestarian budaya daerah melalui pendokumentasian corak keanekaragaman aset budaya 
nasional. Selain itu, penelitian ini bermanfaat bagi generasi penerus, khususnya pewaris seni dan budaya Tobelo.

\section{Tinjauan Pustaka}

Muhamad (2007) melakukan penelitian tentang tarian togal di Pulau Makian. Ia mendeskripsikan dan mengidentifikasi serta menguraikan bagaimana ungkapan-ungkapan dalam tarian togal mencerminkan pola pikir masyarakat Makian Pulau. Muhamad menggunakan konsep Hymes (1970). Dari hasil penelitian ditunjukan bahwa ungkapan bermakna budaya yang digunakan masyarakat Pulau Makian sebagian besar terdiri dari frase, klausa, dan kalimat serta ungkapan-ungkapan tersebut merupakan rangkuman pola pikir mereka tentang nilai-nilai kehidupan. Hal yang membedakan penelitiannya dengan peneliti yakni muhamad kajiannya yaitu kajian etnolinguistik sedangkan peneliti menggunakan kajian linguistik antropologi. Walaupun keduanya meneliti tentang makna budaya. Selain itu terdapat perbedaan juga pada objek penelitian.

\section{Sejarah Pertumbuhan Dan Perkembangan Kesenian Wayang Kulit Di Desa} Karang Rejo Kecamatan Gempol Kabupaten Pasuruan, ditulis oleh Istiqomah, Fakultas Adab, Jurusan Sejarah dan Peradaban Islam, IAIN Sunan Ampel Surabaya Tahun 2006. Skripsi tersebut menitikberatkan pada sejarah pertumbuhan dan perkembangan kesenian wayang kulit di desa karang rejo kecamatan gempol kabupaten pasuruan. Terdapat perbedaan pada objek penelitian.

Anggraini Saragi Turnip (2010) melakukan penelitian tentang Pusat Seni Dan Budaya Batak Toba Di Kabupaten Samosir

Humar Sahman, Mengenali Dunia Seni Rupa, Tentang Seni, Karya Seni, Aktivitas Kreatif, Apresiasi, Kritik dan Estetika, Ikip Semarang Press, 1993

\section{Kerangka Teoritis}

Kerlinger (1973) mengemukakan bahwa teori merupakan seperangkat konsep, definisi dan proposisi yang berfungsi untuk melihat fenomena secara sistematik, melalui spesifikasi hubungan antara variabel sehingga dapat berguna untuk menjelaskan dan meramalkan fenomena. Kerangka teoritis yang digunakan dalam penelitian ini ialah gabungan pendapat para ahli tentang linguistik, seni dan makna budaya tobelo. 


\section{Linguistik Antropologi}

Linguistik antropologi merupakan salah satu cabang linguistik yang meneliti tentang hubungan bahasa dan pola kebudayaan. Cabang ilmu ini melihat hubungan antara bahasa dan kebudayaan. Bahasa merupakan alat utama satu-satunya untuk memasuki kehidupan kelompok masyarakat budaya tertentu (Parera, 1982).

\section{Seni}

Seni pada mulanya adalah proses dari manusia, dan oleh karena itu merupakan sinonim dari ilmu. Dewasa ini, seni bisa dilihat dalam intisari ekspresi dari kreatifitas manusia. Seni sangat sulit untuk dijelaskan dan juga sulit dinilai, bahwa masing - masing induvidu artis memilih sendiri peraturan dan parameter yang menuntunnya atau kerjanya, masih bisa dikatakan bahwa seni adalah proses dan produk dari memilih medium, dan suatu set peraturan untuk penggunaan medium itu, dan suatu set nilai - nilai yang menentukan apa yang pantas dikirimkan dengan ekspresi lewat medium itu, untuk menyampaikan baik kepercayaan, gagasan, sensasi, atau perasaan dengan cara seefektif mungkin untuk medium itu. Adapun beberapa teori seni menurut beberapa tokoh: $\mathrm{Ki}$. Hadjar Dewantara seni adalah segala perbuatan manusia yang timbul dan bersifat indah, menyenangkan dan dapat dapat menggerakan jiwa manusia. Kemudian dari Ahdiat Karta Miharja seni adalah kegiatan rohani yang merefleksi pada jasmani, dan mempunyai daya yang bisa membangkitkan perasaan/jiwa orang lain.

\section{Budaya}

Menurut Nababan dalam Aslinda Syafyahya (2010), bahasa sebagai suatu sistem komunikasi merupakan suatu bagian atau subsistem dari sistem kebudayaan. Namun, merupakan inti dan terpenting dari kebudayaan. Bahasa terlibat dalam semua aspek kebudayaan, paling minim dengan cara mempunyai nama atau istilah bagi unsur-unsur dari semua aspek kebudayaan. Hal yang lebih penting dari itu adalah kebudayaan manusia tidak akan dapat terjadi tanpa bahasa karena bahasa merupakan faktor yang memungkinkan terbentuknya kebudayaan. Hal ini bisa dipahami saat manusia membayangkan sejenak bagaimana bisa mengembangkan unsur-unsur kebudayaan seperti pakaian, rumah, lembaga pemerintahan, lembaga perkawinan dan hukum tanpa danya bahasa. 


\section{Metodologi}

Penelitian ini menggunakan pendekatan kualitatif dengan metode observasi partisipasi oleh Spradley (1997) dan Dell Hymes (1970) alasannya Prosedur penelitian ini menghasilkan data deskriptif yang diperoleh langsung dari informan penutur bahasa yang mengetahui seni dan budayanya dengan baik. Penelitian lapangan yang terarah untuk memperoleh data tentang seni dan budaya Tobelo.

\section{Tempat dan waktu Penelitian}

Penelitian ini dilakukan di Maluku Utara Kabupaten Halmahera Utara, dengan dasar pertimbangan bahwa peneliti mengangkat judul penelitiannya tentang Seni Dan Budaya Tobelo bermukim di Kabupaten tersebut. Selain itu peneliti dari wilayah yang sama sehingga layak dilakukan penelitian terhadap seni dan budaya untuk mengangkat dan mengenalkan aset seni dan budaya yang ada. Lokasi yang dipilih dalam penelitian adalah Kota Tobelo, Kab. Halmahera Utara, Prov. Maluku Utara. Alasan penetapan lokasi ini karena aspek seni dan budaya masih tetap dipertahankan di kota tersebut. Lamanya penelitian adalah 2 (dua) minggu yaitu dimulai pada awal bulan Juli sampai pertengahan mei 2016, namun sebelumnya telah dilakukan observasi pada bulan Juni 2016.

\section{Pemilihan Informan}

Menurut Nida (1946:190), syarat - syarat informan yang baik adalah : memiliki intelegensi yang baik dalam arti mempunyai kematangan mental, memiliki kepribadian yang komunikatif dan pengetahuan yang cukup.

\section{Teknik Pengumpulan Data}

Pada tahap pengumpulan data dilakukan observasi pertisipasi yaitu pengamatan langsung ke tempat berlangsungnya seni dan budaya. Peneliti mengamati jalannya pentasan seni dan budaya yang ditampilkan, mendokumentasikan, data percakapan yang berlangsung antara utusan yang mewakili pihak pentasan seni dan budaya. Selanjutnya wawancara, data yang lebih rinci sesuai dengan kebutuhan peneliti.

\section{Teknik Analisis Data}

Analisis data dilakukan bersamaan dengan pengumpulan data melalui wawancara langsung. Saat melakukan wawancara, peneliti menganalisis jawaban informan berikan. 
Bila jawaban yang diberikan kurang memuaskan maka peneliti memberikan pernyataan lagi sehingga memperoleh data yang cukup. Sugiyono(2009) menyatakan bahwa analisis bahasa meliputi kegiatan reduksi kata, penyajian data dan kesimpulan. Reduksi kata berarti merangkum, memilih hal-hal yang pokok, memfokuskan pada hal-hal yang penting, di cari tema sehingga data yang telah direduksi akan memberi gambaran yang jelas dan mempermudah peneliti untuk melakukan pengumpulan data selanjutnya.

\section{Pembahasan}

\section{Linguistik Antropologi}

Linguistik antropologi merupakan salah satu cabang linguistik yang meneliti tentang hubungan bahasa dan pola kebudayaan. Cabang ilmu ini melihat hubungan antara bahasa dan kebudayaan. Bahasa merupakan alat utama satu-satunya untuk memasuki kehidupan kelompok masyarakat budaya tertentu (Parera, 1982).

\section{Pengertian Seni Tari}

Seni tari adalah seni yang mengekspresikan nilai batin melalui gerak yang indah dari tubuh/fisik dan mimik. Seni tari secara umum memiliki aspek-aspek gerak, ritmis, keindahan, dan ekspresi. Selain itu, seni tari memilki unsur-unsur ruang, tenaga, dan waktu. Ruang berhubungan dengan posisi, tingkatan, dan jangkauan. Posisi berhubungan dengan arah hadap dan arah gerak. Arah hadap, seperti menghadap kedepan, kebelakang, serong kanan, dan serong kiri, arah gerak, contohnya menuju kedepan, kebelakang, memutar, atau zigzag. Tingkatan berhubungan dengan tinggi rens ldahnya posisi duduk dan level tinggi dengan posisi kaki dijinjitkan atau dengan meloncatloncat,. Jangkauan berhubungan dengan gerak yang panjang atau pendek, gerak yang besar atau kecil.

Tenaga sangat dibutuhkan dalam seni tari karena dengan tenaga, tari yang ditampilkan lebih kreatif. Tenaga dalam seni tari sangat berhubungan dengan rasa dan emosi, bukan dengan kekuatan otot. Gerakan tari yang dikendalikan dan diatur dengan tenaga yang berbeda-beda akan membangkitkan kesan yang mendalam, bukan hanya bagi penonton, juga bagi si penari.

\section{Seni Tari Tradisional}

Tari tradisional merupakan bentuk tarian yang sudah lama ada, diwariskan secara turun-temurun, serta biasanya mengandung nilai filosofi, simbolis, dan religious. Sebelum 
bersentuhan dengan pengaruh asing, suku bangsa di kepulauan Indonesia sudah mengembangkan seni tarinya tersendiri. Banyak ahli antropologi percaya bahwa tarian di Indonesia berawal dari gerakan ritual dan upacara keagamaan. Tarian semacam ini biasanya berawal dari ritual, seperti tari perang, tarian dukun untuk menyembuhkan atau mengusir penyakit, tarian untuk memanggil hujan, dan berbagai jenis tarian yang berkaitan dengan pertanian, tarian lain diilhami oleh alam, tarian jenis purba ini biasanya menampilkan gerakan berulang-ulang dan tarian ini juga bermaksud untuk membangkitkan roh atau jiwa yang tersembunyi dalam diri manusia. Tari tradisional Indonesia mencerminkan kekayaan dan keanekaragaman bangsa Indonesia.

\section{Seni dan Budaya Tobelo}

Dalam pembahasan ini terdapat Seni dalam Budaya Tobelo diantaranya :

\section{TARIAN CAKALELE}

Tarian Cakalele adalah tarian perang yang saat ini lebih sering dipertunjukan untuk menyambut tamu agung yang datang ke daerah ini maupun untuk acara yang bersifat adat. Para penari cakalele pria biasanya menggunakan parang dan salawaku sedangkan penari wanita menggunakan lenso (sapu tangan). Cakelele merupakan tarian tradisional khas Maluku.

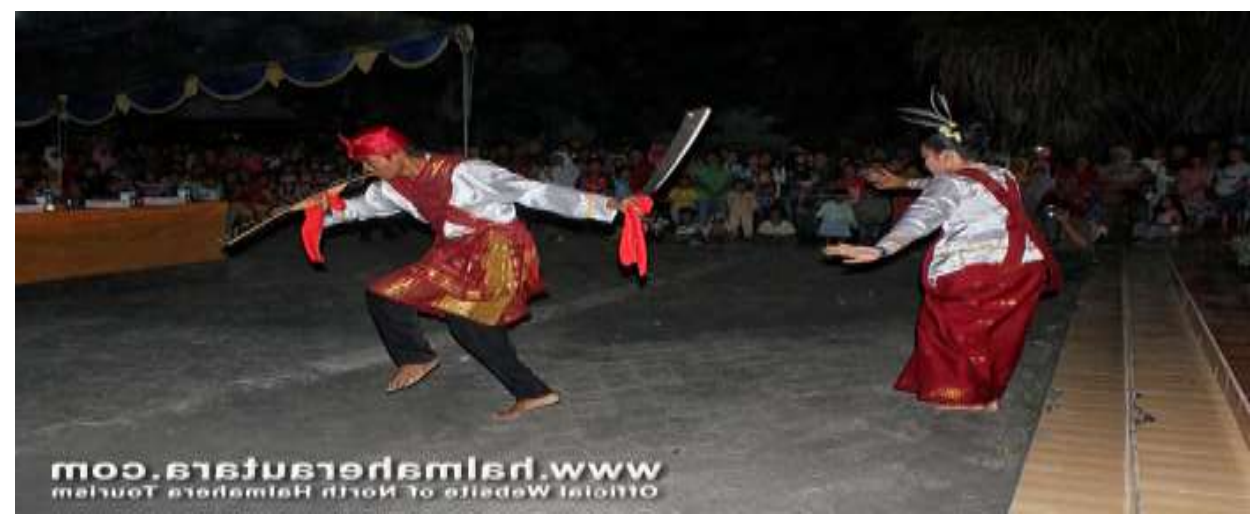

\section{MUSIK YANGERE}

Merupakan musik tradisional masyarakat Halmahera Utara. Musik ini dimainkan secara kelompok dengan menggunakan alat musik tradisional kaste (bass tradisional) dan jup (gitar berukuran kecil). Oleh masyarakat setempat musik Yangere biasanya dimainkan 
dalam rangka menyambut event tertentu dengan cara membawanya berkeliling dari rumah ke rumah.

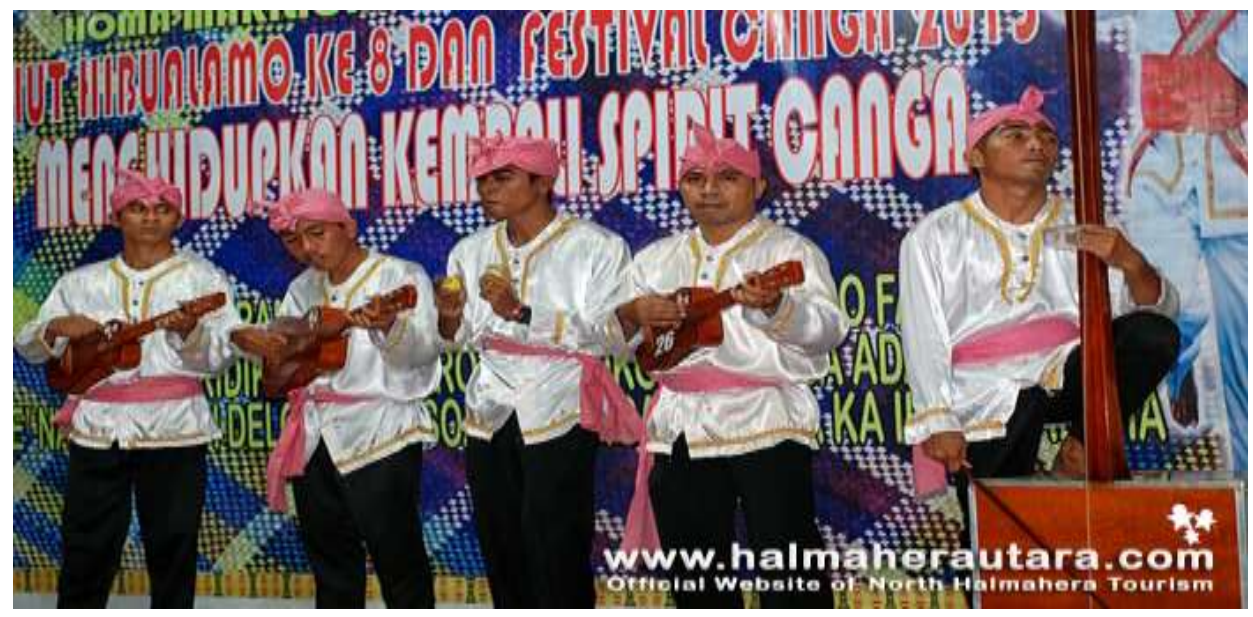

\section{TARIAN TIDETIDE}

Tidetide adalah tarian khas Halmahera Utara yang biasanya dipentaskan pada acara tertentu seperti pada pesta perkawinan adat atau pesta rakyat. Gerakan pada tarian Tidetide memiliki makna tertentu yang dapat diartikan sebagai bahasa pergaulan sehingga Tidetide juga dikenal sebagai tari pergaulan. Tarian ini dibawakan oleh kelompok penari pria dan wanita yang berjumlah 12 orang sambil diiringi tabuhan tifa, gong dan biola.

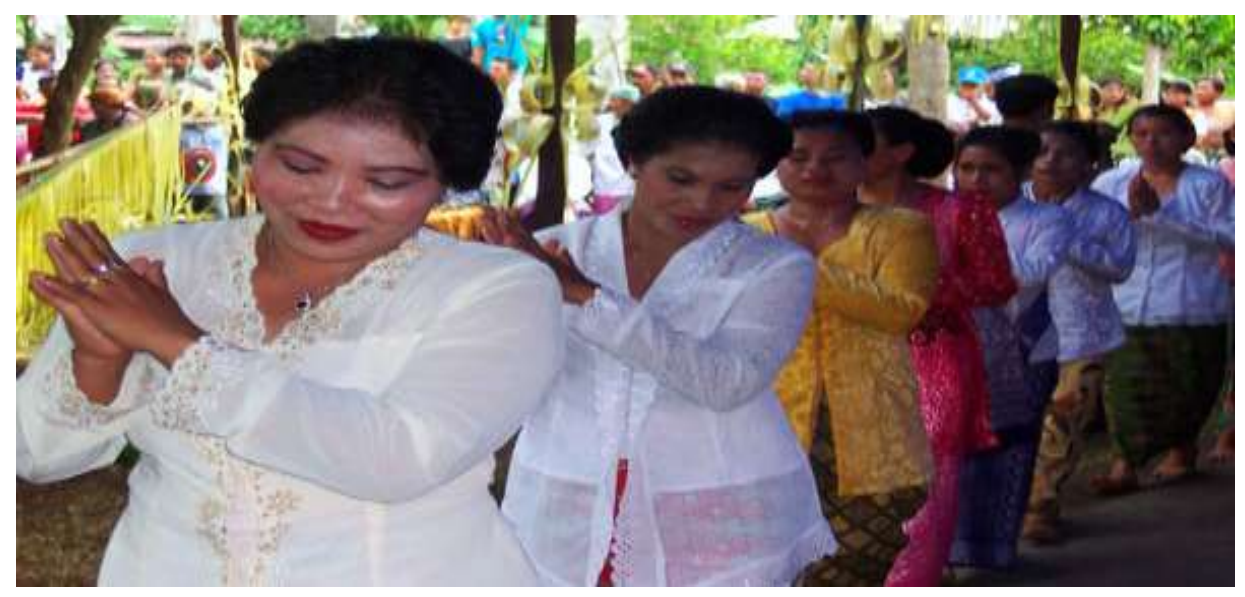

\section{TARIAN DENGEDENGE}

Selain Tidetide, Halmahera Utara juga memiliki Dengedenge sebagai tarian pergaulan yang biasanya dibawakan oleh sekelompok penari pria dan wanita sambil diiringi nyanyian-nyanyian berupa syair pantun yang memiliki makna cinta dan harapan di masa depan. Tidak jarang tarian ini diakhiri dengan sebuah kesepakatan untuk menikah 
antara si penari pria dan wanita. Nyanyian pengiring Dengedenge dibawakan dengan cara saling berbalas-balasan.

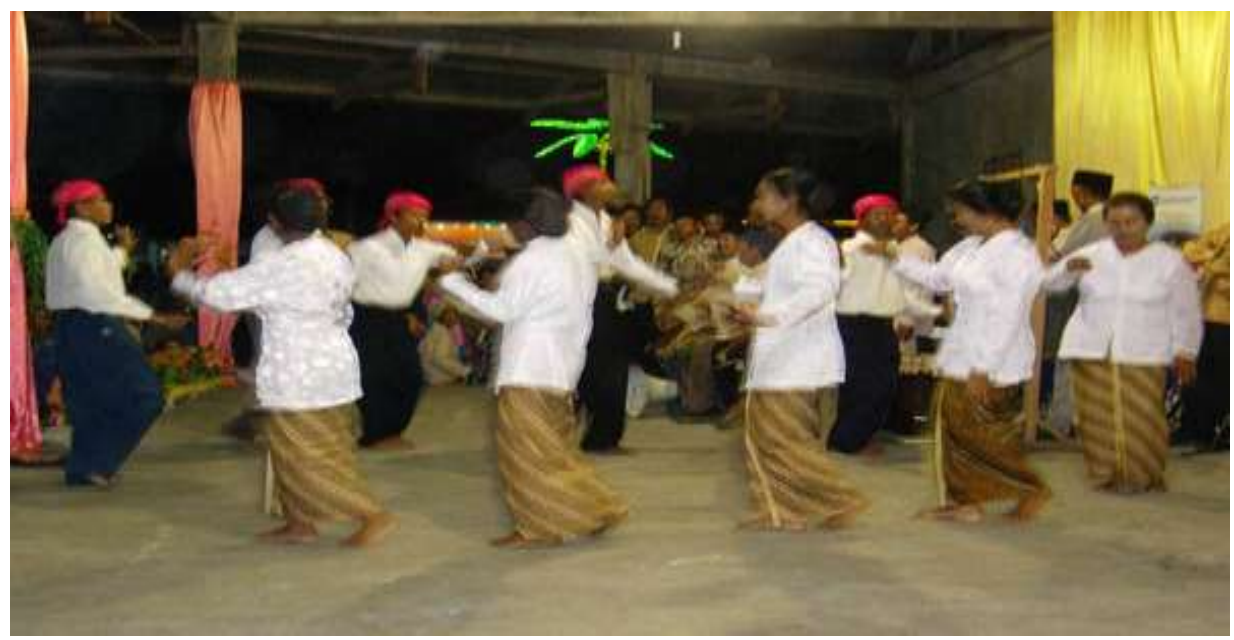

MUSIK BAMBU HITADI

Sesuai namanya, alat Musik Bambu Hitadi dibuat dari bambu dengan menggunakan pengaturan nada musik berdasarkan nada-nada yang dibutuhkan pada lagu yang diiringi. Musik Bambu Hitadi merupakan musik tradisional yang hanya terdapat di Halmahera Utara dengan pemain dan penyanyi berjumlah 15 orang.

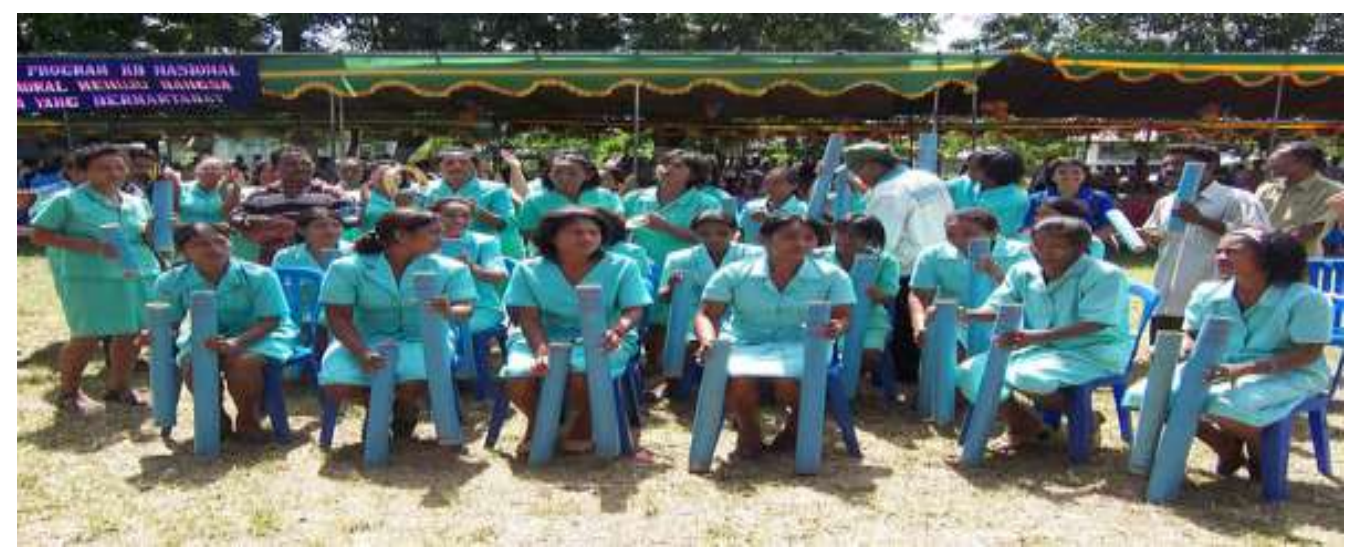

\section{Simpulan}

Seni pada mulanya adalah proses dari manusia, dan oleh karena itu merupakan sinonim dari ilmu. Dewasa ini, seni bisa dilihat dalam intisari ekspresi dari kreatifitas manusia. Seni sangat sulit untuk dijelaskan dan juga sulit dinilai, bahwa masing - masing induvidu artis memilih sendiri peraturan dan parameter yang menuntunnya atau kerjanya, masih bisa dikatakan bahwa seni adalah proses dan produk dari memilih medium, dan suatu set peraturan untuk penggunaan medium itu, dan suatu set nilai - nilai yang 
menentukan apa yang pantas dikirimkan dengan ekspresi lewat medium itu, untuk menyampaikan baik kepercayaan, gagasan, sensasi, atau perasaan dengan cara seefektif mungkin untuk medium itu.

\section{Daftar Pustaka}

Akmadjian, A., R.A Demers, dan R.M Harnish. 1981. Linguistics, An Introduction to language and Communication. Cambridge - London: The M.I.T. Press.

Anggraini Saragi Turnip (2010) Pusat Seni Dan Budaya Batak Toba Di Kabupaten Samosir

Austin, J.L. 1962. How to do things with words. Oxford University Press New york.

Casson, R.W. 1981. Language, Culture, and cognition: Anthopological Perspectives. New York: Macmillan Publishing Co, Inc.

Departemen Pendidikan dan Kebudayaan , Pusat Penelitian Sejarah dan Budaya Proyek Penelitian dan Pencatatan Kebudayaan daerah, 1978/1979, Adat dan Upacara Perkawinan Daerah Dsulawesi Tengah, Palu. 1991. Tata Sajian Upacara Adat Suku Kaili, Museum Negara Propinsi Sulawesi Tengah.

Djajasudarma, T.F. 1994. Wacana: Pemahaman dan hubungan Antarunsur. PT .Eresco. Bandung.

Deend, D. 1987. Adat dan Upacara Perkaeinan di Minahasa, Laporan Penelitian, Manado: Universitas Sam Ratulangi.

Katuuk, E.M. J. Sumarauw, M. E. Tangkilisan, N. ChTuturoong, S. Suharjo 1999.

Pengetahuan, Sikap, Kepercayaan dan perilaku Generasi muda terhadap Budaya Tradisional (Perkawinan Adat) di Kota Palu, Dep. Pend.\& Kebudayaan Sulawesi Utara.

Folley, W .A. 1997. Anthropological Linguistics: An Introduction. Malden: Blackwell Publishers Inc.

Goodenough, W .H. Anthropology Linguistics. In P.L. Garvin, ed. Report of The 7 Annual Raund Table meeting on Linguistics and Language Study. Georgetown University Press. Washington.

Havilaland, W .A. 1985. Antropologi. (Penerjemah: Soekadijo, R.G.) Penerbit Heraty, T. 1984. Aku dalam Budaya. PT Dunia Pustaka Jaya. Jakarta.

Hudson, R.A. 1980. Sociolinguistics. Cambridge University Press. Cambridge.

Humar Sahman, Mengenali Dunia Seni Rupa, Tentang Seni, Karya Seni, Aktivitas

Kreatif, Apresiasi, Kritik dan Estetika, Ikip Semarang Press, 1993

Hymes, D.H. 1964. Language in culture and society A Reader in Linguistics and Anthropology. New York: Harper \& Row.

1974. Foundation in Sociolinguistics: An Ethnographic Approach. University. University of Pennsylvania Press. Philadelphia.

Muhamad, (2007) Tarian togal di Pulau Makian. 